\title{
Study Habits Used by Students at the University of Technology
}

\author{
Ban Kadhim Abed \\ University of Technology /Baghdad \\ ban_aldarraji20152015@yahoo.com
}

\begin{abstract}
The desire of students to study when there is a good chance provided to them is called study habits. When students are not having good habits, they can't use effective study skills. Good study habits make one individual learn more quickly and soundly than the other.

Good student is classified from the bad one according to good study habits. When especially there are video games to play, friends to gossip with and TV to watch, it's natural to not want to study.

In the university life, study is an important part of it and there is no universal method that fits every student or subject. Largely, it is a matter of figuring out what works best for the student, this is called developing practical and good study habits. However, there are some useful methods and guidelines the student can follow to help maximize his/her learning.

For this, a study habits questionnaire from (Virginia Gordon's University Survey: 1997) was used to measure the study habits used by 58 B.A. of computer science students. Results show that most of the students don't have good study habits and need help.
\end{abstract}

Key words: study, habits, students 


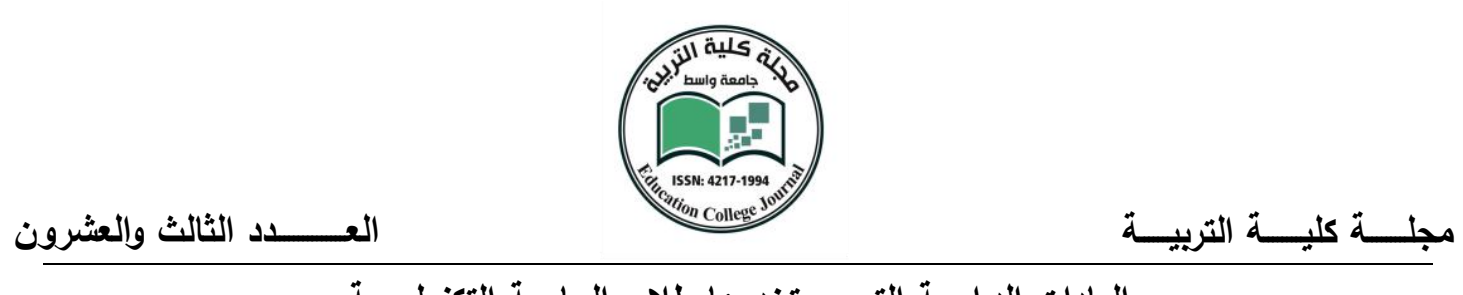

العادات الاراسية التي يستخدمها طلاب الجامعة التكنولوجية

الملخص

ان رغبة التلاميذ او الطلاب للاراسة عند نوفر الفرصة لهم هو مايسمى بالعادات الدراسية. عندما لا

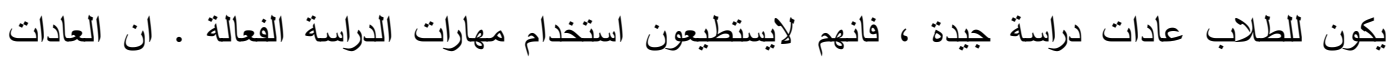

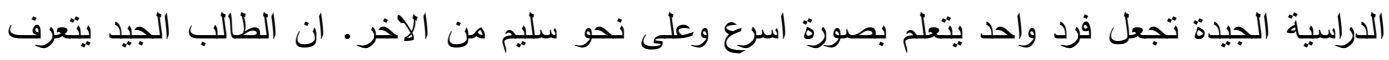

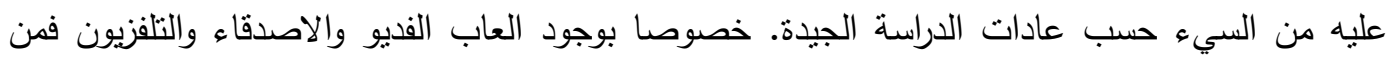

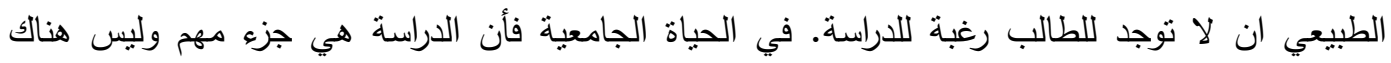

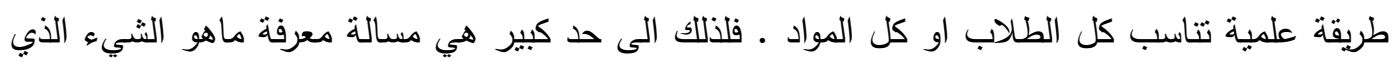

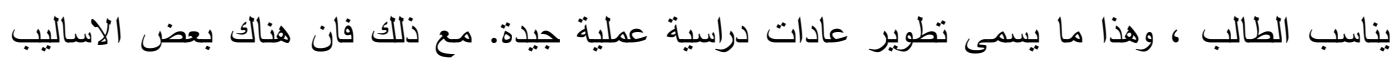
والمبادئ التوجيهية المفيدة التي يسنطيع الطالب انباعها لمساعدنه في تحقيق اقصى حد من التعلم. لهذا

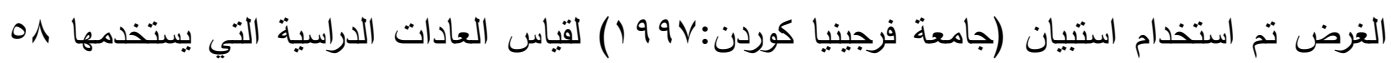
طالب في مرحلة البكالوريوس من طلاب قسم علوم الحاسوب. لقد اظهرت النتائج ان معطم الطلاب لم يكن لديهم عادات دراسية جيدة ويحتاجون مساعدة. 


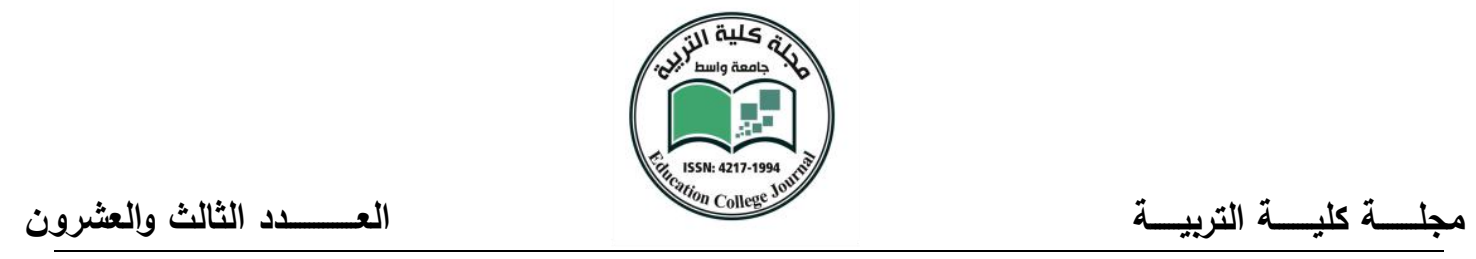

Introduction

Teaching and learning are very important things and cannot be denied in the whole process of education. When teachers have a full knowledge of their subject matter and try to deliver it effectively to their students, only by this way the process can become successful and also when students know the powers they own, and have a good study habits and have the ability to use effective study skills. Knowing and learning the process of how to study involves leaving unpleasant and burdensome study habits and ideas and using habits and ideas which make study fruitful and more enjoyable. What is the reason that one person learn more soundly and quickly than other? Carelessness and ineffective study habits is the main reason for inefficiency in learning. According to New Standard Dictionary of Education, the subject's background to be learned or looked into, and the inclination of pupils or students to study when the opportunity is given, is the definition of study habits. It is not just memorizing facts, successful effective study consists of more than that. To know where and how to obtain important information is what effective study skills involves and the power to make reasoning use of those information.

According to Crow \& Crow (1992) planning definite time table and a good place, and taking brief of well-organized notes is what the effective habits of study includes. A student must decide what is the important information that make his study successful and then form opinions concerning it. All those things must be acted well in the shortest possible time. It is something good for the student learning how to study and using the most appropriate and efficient ways because, knowledge is very important to everyone. Great success in the field of knowledge according to experts' is attributed to good and consistent study habits. Skill and dedication, how to learn, are the key points for learning, like any other activity.

According to (Azikiwe ,1998:106-114) the way and manner adopted by the student , when he plans his particular readings, after finishing classroom hours, is called study habits and consequently to arrive at control of the subject. Good study skills are things that help students to accomplish control in areas of specialization and excellent performance, so they are a good and useful quality to learners while the opposite limits learning and achievement which later leads to failure. Sorenson (1991) stated that one must outline the good basic study habits while study with good understanding as the primary intention. So maintaining 


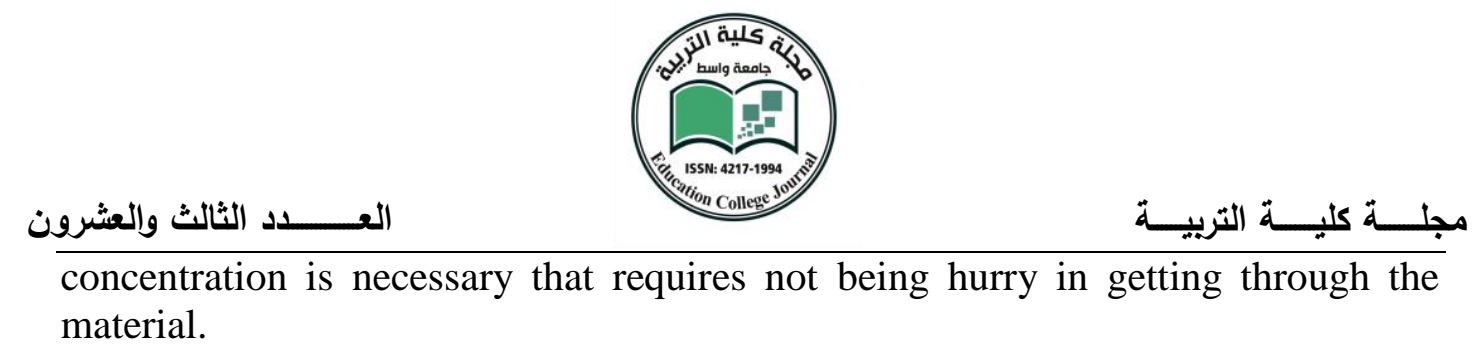

The essential view of learning is concentration, several useful methods and tips looked into by researchers for helping to achieve full subject competence and high grades in examination and consequently to reach the best understanding of their course material. These methods include reading difficulties controlling, critical thinking, index system study, metacognition, time management, concept mapping, time management, raising memory efficacy, and thinking aloud (Hayes, 1989). According to (Chastain \& Thurbor, 1989:893-910) and (Martin,1985:69-83) effective studying techniques have many different types. They adopted "a popular study technique" which is called "the SQ4R method". The "S" and "Q" stand for "Survey" and "Question", and the "4R" stands for "Read", "Recite", "Relate" and "Review". This method is good way to help to prepare for any test in almost any course and is taught in many introductory psychology courses. Different effective learning methods includes:

a) Observation

b) Learning by doing

c) Reading and reviewing

d) Discussing things with others

e) Making Experiments

f) Thinking about new concepts and ideas

g) Re-thinking on what the subject means

h) Practical applications thinking

i) Listening to a paragraph and asking questions

j) Redeveloping-putting a sentence into one's words

\section{The Importance of Education social interaction}

Certainly the greatest instrument in which man has devised for his own progress is education. Therefore all societies have one form of education or another but; the use in which it is put varies. There are some definitions by scientists or ordinary people of the word "study". Some thinks that study as "work" that is usually related with hard school work. Others say that there are other situations in life that the word study may refer to differently from academic work. 
and principles' understanding that involves memorization and application is what study mean.

Kelly (1998) stated that study often involves some form of formal learning and it is the one's mental capacity and application to the acquisition, understanding and organization of knowledge.

Crow and Crow in Okorodudu (2000) said that studying involves hard work, and is a plan of controlling the subject matter. However, study involves social interaction, thinking, feeling, personality, physical activities and health from the individual.

Olatubosun in Oladele (2000) explained that when examining the results of an experiment, the teacher study. Also a lawyer study when he arrange and prepare his case, a merchant do study work when he reads about his product. Study require spending allocated time in a careful effort to study. It should be separated from reading in relaxation time.

Thomas and Robinson (1990) stressed the needs of the learner to use a specific area and a goal-directed way to study. Efficient studying skills consists of a series of inter-linked steps and procedures that are conscious successive.

Okorodudu (1995) maintained that, the word study involves all behavioral patterns (adding knowledge, i.e. verbal, psychomotor, and emotional) that have a settled purpose and applied practices that are adapted by the individual in order to learn something and attain competence.

\section{The Study's purpose :}

The present study investigated and evaluated study habits of computer science students at University of Technology and tried to shed light on the teaching and learning process, study habits and some good techniques for students to develop a comprehensive study of the material that they should study. 


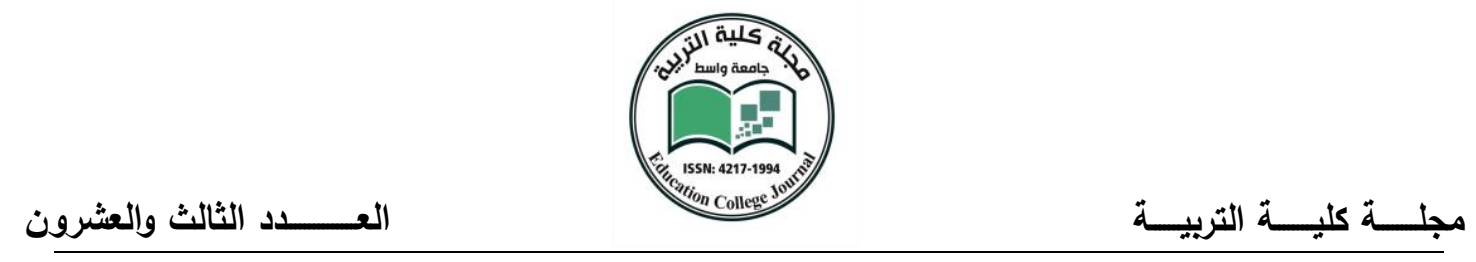

Study Habits

The term study habits according to Good means: the students' way of study whether ordered, effective or ineffective etc.' Good academic performance is determined by good study habits. So to determinants the academic performance and to develop and improve study habits of students, efforts are made. School or university students have to face the emotional cases due to several reasons. Poor study habits they possess and therefore show poor academic performance motivation. Ansari (1980) found that the two significant variables which determine the academic performance of the students are study habits and study behavior. Rusell and Petrie (1992) have cited a research study aimed to find out the relationship between academic performance and study habits and student behavior of university students. Armstrong say that the connection between learning preparedness's with an activity in form of a process is what is called study habits.

The Dictionary of Education defined study habits as students way of study, whether it is effective or ineffective. The method of learning or acknowledgement which is used by a student is the definition of study habits. It can be systematic and unsystematic methods. When the student thinks that his class work is objectless and out of his reach for him, he will be lazy to do that work. Learning tendencies that enable students to work privately is what study habits means. The students' way of study whether systematic, efficient or inefficient is what term study habit can be? Going by this definition, it literally means that positive academic performance is what good study habit produces while inefficient study habit leads to academic failure.

According to Apps (1982) Reed (1996) Rooney \& Lipume (1992) test anxiety will be reduced when there are good study habits, it also develop confidence in himself, raise his ability, and improve his performance. Learning can be an active process because learning is doing and it can be active when a student is involving and taking part in what he / she is trying to learn.

Study habit is a wide concept as it almost mixes all other sub-topics under it , like study method, study attitude, and study skill. Allport (1960) maintains that the mental and natural state of eagerness, that is formed by experience, exercising and have a guiding influence on the person's reaction to all objects and situations 
with which is related to study is what attitude means. Those study attitudes has a great part influencing the academic accomplishment and good study pattern. Positive attitude towards study is adopted by successful learners and that when they do not waste time or energy over what they have to do. Usually if the learner's mental attitude and motivation is positive, the learning experience become pleasant and the learner always tends to avoid the learning experience that is not pleasant. Sometimes negative attitude towards study finds expression in mind such as "although I study hard, I can't remember the material" or the student thinks that lessons are boring and are too long. How we think and feel about people, objects and matters in our environment is the indicator of attitude. Hussain (2000) said that the sensitivities which students have arose towards readings through a period of time is what study attitude refer to, and that study attitude provides great successful achievement possibilities in studies. The knowledge and application of effective study skills or techniques by students is the definition of study method. Several effective study methods and skills are identified by several studies that could be used by students established on the learning environment. These study methods include: knowing what to learn survey, Question, ReadRecite Review, note-taking and summarizing, using artwork and self-questioning and by the help of others.

\section{We can classify Study techniques into two:}

Extensive studying and Intensive studying. Reading a special textbook, magazine or journal in order to have an idea of the basic data in the material is what extensive studying means, surveying and skimming is an example of that type. On the other hand, intensive studying deals with reading a particular textbook or class material in order to reach good and full understanding of that material for the sake of examination.

\section{Study techniques:}

Most students are not aware of what techniques to use to have a proper study position or that they study at wrong times and in wrong places therefore, they do not know how to study probably. Hills and Ballow (2000) try to understand this insufficiency in students' way to study in college students and they try to develop a comprehensive study skill handbook for them. Without applying these skills and methods, effective study cannot be acquired. Some of those methods are: reading, 


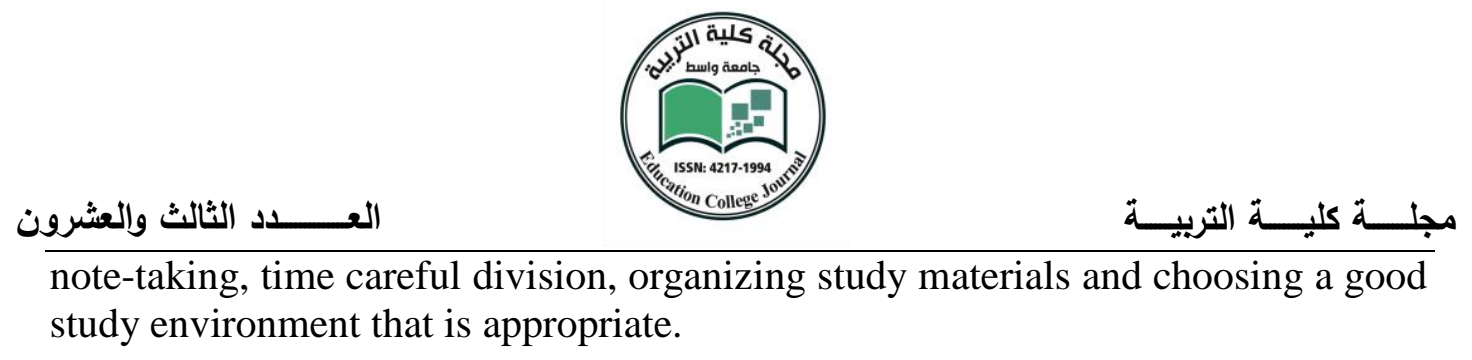

\section{Study Environment:}

Study environment have adverse effect on study, so it must to be taken into consideration first. When the location has a stimuli characteristics, so that study has a significant effect on one's efficiency. The stimulus caused by study position should produce a studying response and no other one. It has been suggested that an important way to take into account is the specifically for study (setting, this study place should be well aired, free of noise and a well-lighted or an open place with a desk and a chair. Ruch (1995) said that it is important to select a desirable kind of chair and desk to sit in for study. These should give the learner a sitting position that makes him feel comfortable. The study table must be wide and have enough space for the student's books and materials, but only it should contains what the student needs at once. Hepher (1990) said that temperature and wetness in the atmosphere have an effect on the human body temperature and can cause a decreasing in the body work and its chemical mechanism. In the study environment, it is important to emphasize the body's need to a fresh air to avoid unneeded fatigue. It was noticed by Hills and Ballow (2000) that some points concerning light might have an effect on the learner for ex. strong light could cause eye pain and headaches. So if possible light color is preferable or the learner can use covered light bulbs to reduce light intensity. So learners should not direct the light in front of them, and that light should not fall directly on the reading table. The place where students have to study should be light adjusted in some way that it is good enough to reduce light intensity or place that light intensity is far away in an enough space from the reading desk. Some learners use music when they study and can't study without it and it is agreed that this music is a good way to relax if it does not disturb the learner or when is used to weaken another outside noise.

\section{Study time's Planning:}

By organizing and planning their time, whatever time students take on studying, the specified time of the day they allocated for setting aside for making work only, students can avoid distraction from regular studies. It is also helpful to specify time for completing ones work and determining time limits for study can also help one to resist recreational distraction (Robinson :1990). Hills and Ballow 
(2000) as regards time planning, they suggests using work diary. This diary allows looking at everything the student has to do and to allocate time to every subject. It should be planned by every student according to his needs and purposes, and so setting aside adequate time to each work so that each work will not take unnecessary time. So when the student organize his time in this way this will help him to lessen worry and doubt that can occur of any extra work will arouse.

\section{Fast and Effective reading:}

Students today have much reading according to curriculum that they take for e.g. in college level they must read about eight subjects at the same time. So the ability of the student to read fast will be a reward. Because as the reader reads quickly, he can catches the meaning and move on the passage better, therefore quick reader understand and retain the material more than slow readers, whereas it takes long time for slow readers to read over each word.

Solomon (1999) said that almost bad readers are often concerned with unimportant details and they are slow too, while fast good readers often grasp a wider understanding of the entire paragraph. Poor readers adopt some bad habits; most of them require using additional body movement in the process of reading, eyes muscles should make the external movement and therefore have inefficient reading. Pointing with fingers or moving the lips of the student, i.e. extra body movements do not help the reading process but often slowing it down.

Slow reading can however be used in some cases according to the subject matter of reading and the purpose, Maddox (2002) developed a different types of reading and he stressed that these types of reading changes according to the student. Those include skillful reading, discovery type and revision reading, vital and reading for pleasure.

\section{Concentration:}

Effective study is the ability to direct the learner's attention on the job at his hand. Robinson (1990) outlined five important circumstances that might affect the aspect of concentration. They include poor lightening and physiological conditions, distractions associated with other activities (internal and external situations), and study materials that is not convenient. Oladele (2000) suggested that an appropriate place of study that students could choose can motivate them to 
study to avoid external distraction. Once they have such good environment that is associated with study only, they will avoid distraction things such as doubt and anxiety, day stargazing, mental and physical tire that destroy the concentration power. Personal problems are the greatest preventive to concentration that still and continue flashing on student's mind if not properly removed and tackled.

\section{Comprehension:}

There is no use in reading without comprehension. Robinson (1990) stated that effective study habit involves reading the person's head instead of his eyes. Read with the motivation of looking for what is the important thing in the material and classifying what is just for explanation and what the student must learn. Robinson suggested that the pre-comprehension techniques help students in comprehension and speeding it up. Understanding the basic concepts is the important thing that many students don't realize, those simple basic conceptions that seem to be simple and applicable to them but later they will realize that without learning those basics adequately, things that are harder will also become difficult to comprehend. The student must search for the meaning of what the writer meant in his writings so that to know what he emphasized in his writing so that students can overcome the obstacle of not understanding what they read.

\section{Remembering:}

The ability of the learner to recall what he read is a critical skill. Retaining past Knowledge is what remembering means. In remembering, Hallas (2002) thought that the memory trace is established on the mind of the person and begin to have a sensory effect, then the traces becomes deeper and therefore are more permanent by repetition.

Either recall or recognition is what remembering involved. Recall is essential for the replication of stuff that is not in reality introduced before the senses at the present moment.

According to Oladele (2000), recognition, recall, reproduction and performance are the four kinds of remembering, he thinks the failure to recall of the student occurs from not doing practice. He also asserted that there are four kind of remembering i.e. performance is also can be defined as the carrying out of habits that are learned well and that they later become highly robotic. 
But according to Hallas (2002), the term remembering has three parts: - the first is pay attention to something that is linked with short term memory part, the second one and the third one is respectively thinking about and using the material linked with long term memory. Actually without training to think about what they have read, most students make the error of reading and re-reading. In remembering, the most effective technique is that studying the passage or diagram at a given period of time. Immediately, the student should try to reproduce it later more and more at some periods of time, for instance, every day studying for a period of one week and then every week for a period of one month. It has been found that this method is very useful and is known as repeated reproduction.

\section{Note-taking:}

It is believed that note-taking is one of the activities that help the learning and remembering process and accordingly leading to academic success. When notetaking properly done, for a matter of fact the process requires concentration and understanding necessary facts, it also involves reading lectures and writing or listening to it and writing down briefly the points. It is not an easy task as it seems to be when we hear the word note-taking, for it involves from the student having the thought and the ability to hear. The students that have slow listening ability and efficiency, note-taking may have damaging effects. For this, Derville (1998) suggest the use of a set of short abbreviations to help the student, for ex: "I" for important, "N" for not required .... Etc. And those abbreviations could be of great help to the slow writer. Also the student should take care to include only relevant information in a note, whether it is taken from a book or a lecture. It is suggested to follow the following procedure:

a. Read carefully throughout the text.

b. Read again through it then pick out the central points that it is covered by the section and write them down as headings on separate place or paper.

c. For each key point in the material make a note on pieces of paper. It make the study varied and more stimulating when using them for a second time in a reading that has a similar points since some books may have points not controls and explained in the first text book,. If these notes are not reviewed systematically and on a regular basis before examination, it would become a useless thing. 
Okorodudu (2000) emphasized that a student should have a special memory to study or it will be difficult for him to control the study material and recall it in an accurate way with all its main points and relevant details that is found in it, just by reading it.

8. The model of SQ3R: it was developed by Hail-Quest and Reviewed (2000) and it is an effective formula and elaborated upon by several other authors. Preparation is the main principal for learning and the knowledge of results is its main emphasis.

"S" means survey

"Q" means Question

"3Rs" stand for Read, Recite and Review

\section{a. Survey:}

Oladele (2000) suggested that the student use a section of a text book, or a diary, article, in doing survey, using those studying references depends on what the student wishes to study, first he reads the section headings to arrive to the universal idea of what the section is talking about, by reading and searching in the introduction and summary he may found if there is any of them in the chapter. At the beginning, reading few sentences of the paragraphs will help and also reading at the end of it, then he makes brief written records of few words, terms and main ideas necessary for him. This is important in creating some outlooks and to be familiarized with the author's style and the structure of the material.

Akinboye (2000) said that the first important step for the student is to look first at the table of contents; preface and read each topic or scan. This scanning makes the student become familiar with the arrangement of the material as a whole by providing him with a general idea and factual information about a general feature of the information from which the material might be related. This initial reading is important and makes the reader recognize what to anticipate. So this scheme allow the student originate a personal advanced ordered and organized thoughts.

\section{b. Question:}

When student arrange questions for him or collect past questions related to the special study work as a guide for him. Those questions concerning the materials enable the student to arise a set of concepts that corresponds the thoughts that will 
be studied by him. Turning the important headings of the chapters into questions like for ex who, where, what, why and how questions is one of the best techniques for setting questions. Those student-generated questions are very beneficial. (Frazier and Schwart ,1995:628-632) carried on a research paper for senior high school students. Those students as they studies a prose passage set questions for themselves either by themselves or with other students during sessions. Results showed that recalling materials was higher in the questioning report than in the studying process only, it is proposed that students make a great use of past questions in studying for external examinations or General Certificate of Education.

\section{c. Reading:}

The vital part of reading is to grasp the meaning of the short passage as a whole. In order to reach the literal meaning of the chapter, students spend much time in reading to get that. The students by reading become familiarized with many content ideas that otherwise would have been neglected when making survey. The major aim should be reading with the purpose to understand. For the student reading each line is an important thing then taking notes of each sentence in the materials and sequencing the cases or the organization of concepts. Hills and Ballow (2000) illustrate that reading and understanding those special words and sentences will reveal the intended meaning in the passage and make it clear to the student, not for one time, reading should be for various times till the student grasp the intending meaning of the passage. It is advised that when reading, the student in order to concentrate should be in a relaxed mood.

\section{d. Recite:}

Lovell (1993) was one of the most former psychologists to use a learning strategy on recitation. In his study, he chooses children in classes 5-7 to memorize a diagrams or light life story. Obviously outcomes showed positively that the recitation process struck in the children's learning. Lovell (1993) stated that it is a good idea for the student to repeat to himself or to his friend, or he can write it on a piece of paper, making use when necessary of some cues, instead of re-reading that material in order to learn it. In relevant experimental evidence, he said, the more time dedicated to drilling, the sooner and more immediate will be the rate of learning that material, with both children and adults. Later there was a study 
carried out by Del Giono, (1998), further stressed the importance of recitation. He compares between the two procedures of read-recite and read and re-read. In these two compared groups, he examined recalling the materials by those students right away after study and a one week later. Students' score of read- recite group was importantly greater on both tests than the student when they check on their own attempts (read-re-read). Though recitation is advantageous, it is noted that it only can work and give consequences when materials are short and have been well perceived.

\section{e. Review:}

As an important study strategy as recitation, review equally is very useful; remembering and practicing of information presented in a study is the definition of review. Aiding of both immediate remembering and long-term remembering is the major advantage. When students experience the material for many times, the tendency are to be familiarize the material while they were being reminded of that materials besides those points that they may have neglected or forgotten. Lovell (1993) affirmed that thorough learning the remembering ability can be aided, and by using a suitable period of the day to study, by reviewing all the time without interruption and by avoiding interference situations. Also he pointed out that when learning the materials that are forgotten partially and study it again, so the forgetting rate of that material is dumber after the re-studying and it becomes lower after further periods of time in looking again to it. This process takes much of the student's time as it appears and can be applied only by those students who decided to study for higher degrees.

\section{Research Methodology}

This study adapted study habits questionnaire (Adapted from: Virginia Gordon's University Survey: A Guidebook and Readings for New Students) to analyze and measure the study habits of 57 B.A. students of computer science at the University of Technology. The students' ages ranged from 18 to 20 years.

Content and face validity was checked by experts in Psychology and education (see table 1). Data collected were analyzed with simple statistical tool which is the t-test. 


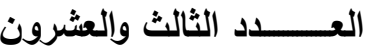

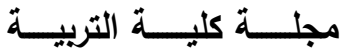

Table 1 (names and positions of jury members)

\begin{tabular}{|l|l|l|l|}
\hline No. & \multicolumn{1}{|c|}{ Academic rank } & \multicolumn{1}{|c|}{ Name } & \multicolumn{1}{c|}{ College } \\
\hline 1 & Professor & Al-Rifia , Fatin & $\begin{array}{l}\text { College of Education/Ibn Rushd/ } \\
\text { University of Baghdad, Ph.D.in ELT }\end{array}$ \\
\hline 2 & Assistant Professor & Al-Noori, Bushra & $\begin{array}{l}\text { College of Education/Ibn Rushd/ } \\
\text { University of Baghdad, Ph.D.in ELT }\end{array}$ \\
\hline 3 & Instructor & Mizher, Dhea' & $\begin{array}{l}\text { College of Education/Ibn Rushd/ } \\
\text { University of Baghdad, Ph.D.in ELT }\end{array}$ \\
\hline 4 & Instructor & Arif, Ali & $\begin{array}{l}\text { College of Education/Ibn Rushd/ } \\
\text { University of Baghdad, Ph.D.in ELT }\end{array}$ \\
\hline
\end{tabular}

\section{Study Habits' questionnaire:-}

This questionnaire has six categories (time management, study environment, exam preparation and test taking skills, note -taking, reading skills, writing skills and math skills). A Likert scale of 1 to 4 of always (A), generally (G), sometimes $(S)$, and $\operatorname{rarely}(R)$ was used in measuring responses of the students (see table 2).

\section{Results and Discussion}

The present study investigated and evaluated study habits of computer science students at University of Technology. The study concerned with the degree of the general study habits of computer science students. Table 2 presents the students' study habits. 


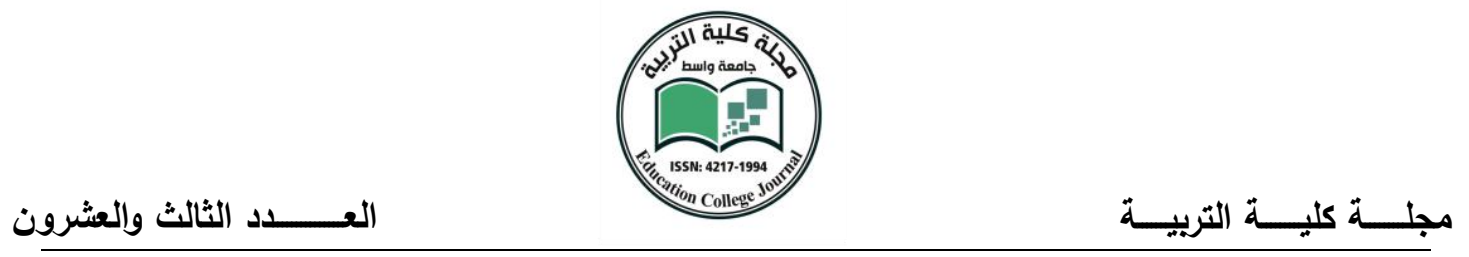

Table (2) Study Habits' questionnaire Time Management

\begin{tabular}{|c|c|c|c|c|c|}
\hline \multicolumn{6}{|c|}{ Time Management } \\
\hline No. & & A & G & $\mathrm{S}$ & $\mathrm{R}$ \\
\hline 1 & For each semester do you make a master schedule? & & & & \\
\hline 2 & Do you update this schedule weekly/ or daily? & & & & \\
\hline 3 & Do you keep to this schedule? & & & & \\
\hline 4 & $\begin{array}{l}\text { Do you set aside some time for exercise and connecting } \\
\text { with your friends? }\end{array}$ & & & & \\
\hline 5 & Do you sleep for six hours at least each night? & & & & \\
\hline 6 & $\begin{array}{l}\text { Do you allot time to study for every hour in class at least } \\
2 \text { hours? }\end{array}$ & & & & \\
\hline 7 & Do you make your assignments and finish it on time? & & & & \\
\hline 8 & Do you attend your classes regularly? & & & & \\
\hline \multicolumn{6}{|c|}{ Study Environment } \\
\hline 9 & Do you study at the same time regularly? & & & & \\
\hline 10 & Do you have a special area where you always go to study? & & & & \\
\hline 11 & Is your study area away from noise and any distractions? & & & & \\
\hline 12 & When you study, do you have all your supplies near you? & & & & \\
\hline 13 & Is your study area comfortable? & & & & \\
\hline 14 & $\begin{array}{l}\text { Can you study without getting up, waist time or taking } \\
\text { snack or watching TV or take phone breaks for at least a } \\
\text { half hour? }\end{array}$ & & & & \\
\hline 15 & $\begin{array}{l}\text { When your friends know you want to study, do they leave } \\
\text { you alone? }\end{array}$ & & & & \\
\hline 16 & Do you use the time between classes to study? & & & & \\
\hline \multicolumn{6}{|c|}{ Exam preparation and test taking skills } \\
\hline 17 & For each class, do you study every day? & & & & \\
\hline 18 & $\begin{array}{l}\text { For major exams, do you start reviewing or examining } \\
\text { materials at least } 3 \text { days in advance? }\end{array}$ & & & & \\
\hline 19 & For study, do you belong to a study students' group? & & & & \\
\hline 20 & $\begin{array}{l}\text { If there is an extra help lessons or provided by the } \\
\text { instructor, do you attend it? }\end{array}$ & & & & \\
\hline 21 & At exam time, do you know in advanced the sort of tests & & & & \\
\hline
\end{tabular}




\begin{tabular}{|c|c|c|}
\hline \multicolumn{3}{|c|}{ العــــــد الثالث والعشرون } \\
\hline & $\begin{array}{l}\text { you will take, i.e., essay test, multiple choice test, and be } \\
\text { familiar with how to prepare for different types of tests? }\end{array}$ & \\
\hline 22 & $\begin{array}{l}\text { Are you able to anticipate the types of questions that will } \\
\text { come on test? }\end{array}$ & \\
\hline 23 & Can you take your test at the allotted period of time? & \\
\hline 24 & $\begin{array}{l}\text { Do you examine the test with the teacher and analyze it to } \\
\text { see where you had problems if you do not do well on a } \\
\text { test? }\end{array}$ & \\
\hline \multicolumn{3}{|c|}{ Note -taking } \\
\hline 25 & $\begin{array}{l}\text { In class, are you able to understand the concepts, take } \\
\text { notes and follow up with the instructor at the same time? }\end{array}$ & \\
\hline 26 & $\begin{array}{l}\text { Do you have an effective system of rules concerning note } \\
\text { taking? }\end{array}$ & \\
\hline 27 & $\begin{array}{l}\text { After each class, do you review your notes in a preferred } \\
\text { way? }\end{array}$ & \\
\hline 28 & $\begin{array}{l}\text { Do you know what are the important cues that you have } \\
\text { to write them down? }\end{array}$ & \\
\hline 29 & $\begin{array}{l}\text { When you read class materials do you make notes, in } \\
\text { addition to highlighting? }\end{array}$ & \\
\hline 30 & $\begin{array}{l}\text { Can you write class notes or notes from texts by your own } \\
\text { words? }\end{array}$ & \\
\hline \multicolumn{3}{|c|}{ Reading Skills } \\
\hline 31 & $\begin{array}{l}\text { For history-type material, can you read and learn at 12-15 } \\
\text { pages per hour rate? }\end{array}$ & \\
\hline 32 & $\begin{array}{l}\text { Do you have the material read before the lecture and } \\
\text { maintain the readings for all your classes? }\end{array}$ & \\
\hline 33 & $\begin{array}{l}\text { The material you read, can you understand it without re- } \\
\text { reading it for a second or third time? }\end{array}$ & \\
\hline 34 & $\begin{array}{l}\text { Do you read the chapter headings and outlines first when } \\
\text { reading a text? }\end{array}$ & \\
\hline 35 & $\begin{array}{l}\text { Reading for literature, social science, or science classes, } \\
\text { for those do you adjusts your reading styles? }\end{array}$ & \\
\hline 36 & $\begin{array}{l}\text { When you are most awake during the time of day, do you } \\
\text { do your study-reading? }\end{array}$ & \\
\hline
\end{tabular}




\begin{tabular}{|c|c|c|}
\hline \multicolumn{3}{|c|}{ العــــــــد الثالث والعشرون } \\
\hline \multicolumn{3}{|c|}{ Writing Skills } \\
\hline 37 & $\begin{array}{l}\text { Do you control and are comfortable with the rules of } \\
\text { English grammar, punctuation, and spelling? }\end{array}$ & \\
\hline 38 & $\begin{array}{l}\text { For writing an assignment, do you have a clear idea of } \\
\text { what the instructor wants from you? }\end{array}$ & \\
\hline 39 & $\begin{array}{l}\text { When you want to write a paper, do you first make an } \\
\text { outline of it? }\end{array}$ & \\
\hline 40 & $\begin{array}{l}\text { Do you know how to use the library or Internet as a } \\
\text { source for you and search your topic if you are assigned a } \\
\text { research paper? }\end{array}$ & \\
\hline 41 & $\begin{array}{l}\text { Do you start and complete your research in time if you are } \\
\text { asked to without delaying it? }\end{array}$ & \\
\hline 42 & $\begin{array}{l}\text { In writing, are you able to communicate effectively } \\
\text { through it? }\end{array}$ & \\
\hline \multicolumn{3}{|c|}{ Math Skills } \\
\hline 43 & $\begin{array}{l}\text { When you enroll in math class, do you have a good } \\
\text { control of the requirement skills for it? }\end{array}$ & \\
\hline 44 & $\begin{array}{l}\text { Do you finish your homework assignments always and } \\
\text { work the problems and solve it before looking at the } \\
\text { solutions? }\end{array}$ & \\
\hline 45 & $\begin{array}{l}\text { When you don't understand a concept in class, do you } \\
\text { participate and ask questions? }\end{array}$ & \\
\hline 46 & Do you miss two math classes at most per a semester? & \\
\hline 47 & $\begin{array}{l}\text { Can you explain the solution of all the problems on a } \\
\text { math test to another student who didn't know how to } \\
\text { solve it? }\end{array}$ & \\
\hline 48 & $\begin{array}{l}\text { Do you have enough time to review for calculation errors } \\
\text { and "stupid" mistakes after taking your tests, like } \\
\text { misplaced + or - signs? }\end{array}$ & \\
\hline
\end{tabular}




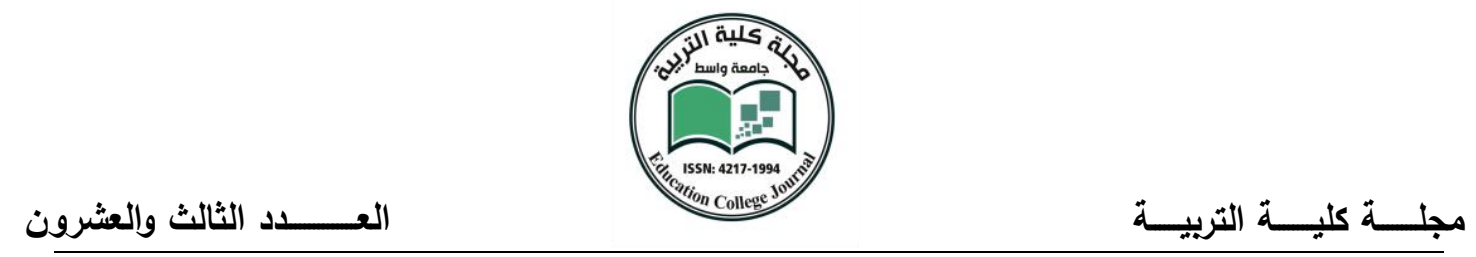

Findings:

Data collected by the questionnaire was analyzed by using of the mean score and independent sample t-test. The findings drawn out from the data analysis are given below (see table 3 ).

$P$ value and statistical significance:

The two-tailed $\mathrm{P}$ value is less than 0.0001

By conventional criteria, this difference is considered to be extremely statistically significant. So there is a significant difference between the students' study habits in the group collected and tested. Results of t-test shows that the students need to arrange their study habits but still need improvement.

In total 7 students show good study habits and 50 students were relatively desirable, and 10 were having poor study habits and need help.

Confidence interval:

The hypothetical mean is 0.00

The actual mean is 25.00

The difference between these two values is 25.00

The $95 \%$ confidence interval of this difference: From 23.22 to 26.78

Intermediate values used in calculations:

$$
\begin{aligned}
& \mathrm{t}=28.1926 \\
& \mathrm{df}=56
\end{aligned}
$$

standard error of difference $=0.887$

$\mathrm{SD}=6.96$

$\mathrm{SEM}=0.89$

$\mathrm{N}=57$

Table 3 Descriptive statistics for the study habits questionnaire

\begin{tabular}{|c|c|c|c|c|c|c|c|c|}
\hline $\begin{array}{c}\text { The general } \\
\text { questionnaire }\end{array}$ & $\mathrm{N}$ & Mean & $\begin{array}{c}\text { Std. } \\
\text { Deviation }\end{array}$ & SEM & $\begin{array}{c}\text { Std. } \\
\text { Error } \\
\text { Mean }\end{array}$ & df & t-value & p-value \\
\hline & 57 & 25.00 & 6.96 & 0.89 & 0.887 & 56 & 28.1926 & 0.0001 \\
\hline
\end{tabular}


According to its importance in the learning process, study habits seems not improved and the students have not achieved the necessary instructions to improve their study skills and habits, and most of the students have moderately desirable study habits. There must be an education course to be taught to the students to teach methods and study habits and how to develop them.

\section{Conclusion}

Study habits has a significant effect on learning, when the student have good study habits, he can understand and learn the materials easily. It is essential to study and plan to improve methods and study habits of students. For example in creating a good study environment, there are many barriers that the students face. The best and recommended place for quiet study is the library.

The student's study habits are teachable and learnable and researchers and teachers can take several steps in this field. Courses of correct study habits can be held for students when they enter college to gain the knowledge in this field. Deficiency of efficient study habits is a problem to all learners so the researcher try to present some methods to teachers and learners to take into account when studying or teaching how to study. 


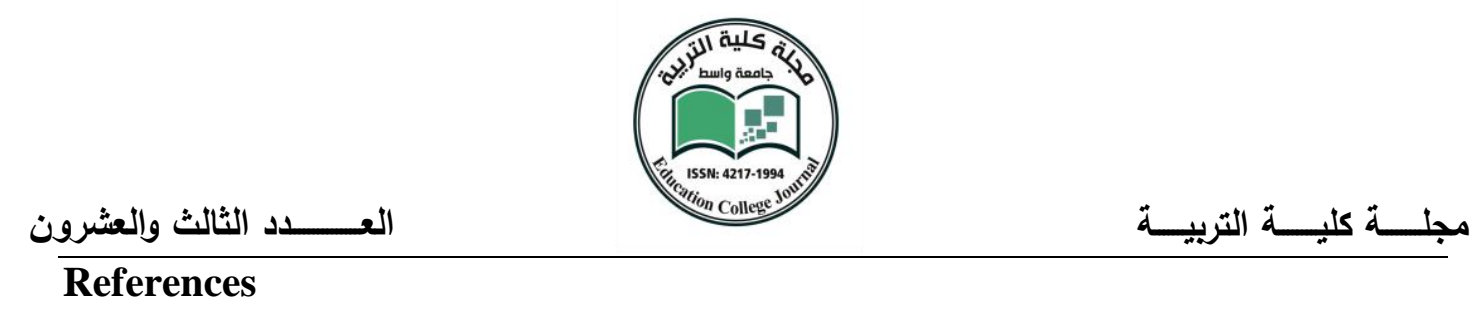

Azikiwe, U.(1998) Study Approaches of University Students: WCCI Region II Forum Vol.2,Lagos.Pp106-114.

Apps, J. (1982). Study skills for adults returning to school. New York: McGraw- Hill.

Ansari, Z.A. (1980) 'Study Habits and Attitude of Students', Development and Validation of Questionnaire measures. Islamabad: National Institute of Psychology.

Akinboye, J.O., 2000. How to study and Pass Important Examinations. Ibadan Maritime Printer.

Armstrong, Study is Hard Work, Harper and Brothers, New York, 1956.

Cater V. G., D. K. Phi, Dictionary of Education, McGraw-Hill, New York, 1973.

Crow, R.D.and A.Crow,(1992) Educational Psychology. American Book Co., N.Y., USA.

Chastain,G., \& Thurber,S.(1989). The chameleon effect: The perception- behaviour link and social interaction. Journal of Personality \& Social Psychology, 76(6) 893-910.

Del Giono, S., 1998. Effects of Retention on the Acquisition of Prose. Unois Dorsey Press

Derville, L.M.T., 1998. The Use of Psychology in Teaching. Longman, London.

Frazier, L.T. and B.J. Schwart, 1995. Effects of questions production and answering on prose recall J. Edc. Psychol ., 67 (5): 628-635.

Good, C.V., Dictionary of Education (3rd Ed.), McGraw Hill Book Company, New York, 1973.

Hayes, John R.(1989). The complete problem solver.Hillsdale, NJ: Lawrence Erlbaum Publishers.

Hussain, A (2000) Effect of Guidance Services on Study Attitudes, Study Habit and Academic Achievement of Secondary School Students.

Hills, P.S. and H. Ballow, 2000. Effective Study Skill. Pan Books Ltd. , London.

Hepher, H.W., 1990. Psychology Applied to Life and Work. Pan Books Ltd., London.

Hallas, C.H., 2002. The Core and Training of the Mentally Retarded. Bristol John Wright and Sons, Bristol. 
$\frac{}{\text { Kelly, W.A., 1998. Educational Psychology. Bruse Pub. Co., Milwaukee. }}$

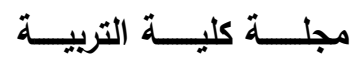

Lovell, K., 1993. Educational Psychology and Children. Hodder and Stronghton, London.

Martin,M.A.(1985). Students' applications of self-questioning study techniques: An investigation of their efficacy. Reading Psychology, 6(1-2), 69-83.

Mace, C.A., 2002. The Psychology of Study. University of Penguin Book Ltd., Hasmondsworth, Middlesex, USA.

Maddox, H., 2002. How to Study. Pan Books Ltd., London.

Oladele, J.O., 2000. Fundamentals of Psychological Foundations of Education. Johns-Lad Publishers Ltd., Lagos.

Okorodudu, R.I., 2000. Intelligence and learning. Adolescent Psychology. Delta State University Press, Absaka, Nigeria.

Reed, W. (1996). Study skills: The key to Student Success. Dubuque, IA: Kendall/Hunt Publishing Company. Rooney, R \& Lipume, A. (1992). Learn to be the Master Student. Silver Spring MD.Mayble Publishing Company.

Russel, R.K. and Petrie, T.A. (1992) 'Academic Adjustment of College Students: Assesment and Counselling' in Steven D. Brown, Robert W. Lent.Handbook of Counseling Psychology.

Robinson, F., 1990. Principles and Procedures in Student Counseling. Harper and Row, New York.

Ruch, F.L., 1995. Psychology and Life. Scot Freeman and Co., New York.

Serenson HP. (1991). Psychology in Education. McGraw Hill Book. Co. Inc., N.Y., USA.

Solomon, R.H., 1999. Personal Adjustment to Reading Success and Failure; Clinical Studies in Reading. McGraw-Hill, London.

Thomas, A.E.L. and C. Robinson, 1990. Improving Reading in Every Class. Allyn and Bacon, Boston.

Virginia Gordon's University Survey:1997, A Guidebook and Readings for New Students 